\title{
On Rights of Inheritance and Bequest
}

\author{
lain Brassington ${ }^{1}[$
}

Received: 24 September 2018 / Accepted: 13 March 2019 / Published online: 23 April 2019

(c) The Author(s) 2019, corrected publication 2019

\begin{abstract}
What attitude would a just state take to the inheritance of property? Would confiscatory taxes on the estate of the deceased be morally acceptable, or would they represent some kind of wrong? While there is a good amount of political philosophical scholarship that considers the desirability of inheritance tax, there appears to be little that has considered it from the perspective of rights theory, asking what kind of thing a right to bequeath or to inherit would be, and whether those putative rights are defeasible. I argue here that putative inheritance rights are best made sense of as interest-rights. However, while agents may have interests in bequest and inheritance, it is also plausible that the community as a whole has interests that would be served by a confiscatory inheritance tax; and if inheritors' and testators' interests are strong enough to generate a prima facie right, it is also plausible that the community would have a competing prima facie right. Importantly, there is reason to think that the community's interests trump the testator's and the inheritor's; if there are thoroughgoing rights in respect of inheritance, it is not at all clear that a highly confiscatory tax would violate them.
\end{abstract}

Keywords Inheritance $\cdot$ Bequest $\cdot$ Tax $\cdot$ Rights $\cdot$ Justice $\cdot$ Equality

\section{Intuitions About Justice and Inheritance}

What kind of attitude would a just state take to the inheritance of property? Many people make wills in which they express a desire that, after their death, this or that item or amount of money should pass to this or that person. Those wills have, and we expect them to have, a certain legal status. We expect our wills to be enforceable; correspondingly, we expect that if we are named as a beneficiary, we will get what we are bequeathed as a matter of right. We expect sometimes also that we will get things that we are not bequeathed as a matter of right, as when property devolves to us from someone who has died intestate.

Iain Brassington

iain.brassington@manchester.ac.uk

1 CSEP/School of Law, University of Manchester, Oxford Road, Manchester M13 9PL, UK 
The intuition that some kind of inheritance should be allowed and protected within a legal system is matched by another powerful intuition, articulated by thinkers such as Rawls, which is that a just society is one in which a person's prospects, and the resources to which they have access, do not depend on undeserved factors. On lists of these factors we would not be surprised to find things such as accidents of birth. Yet it is reasonable to assume that the descendants of the wealthy do enjoy access to certain resources by accident of birth, and that inheritance can skew a social system towards fundamental inequality: Piketty estimates that "nearly onesixth of each cohort [born between 2010 and 2020] will receive an inheritance larger than the amount the bottom half of the population earns through labour in a lifetime", adding that this bottom half "largely coincides with the half of the population that inherits next to nothing" (Piketty 2014, 421). This seems to be unfair in its own right; but can be argued further that inheritance distorts the background conditions under the terms of which people live their lives, and that those who receive a substantial inheritance will have brighter prospects than those who don't. In Stuart White's words:

[W] ealth confers opportunity in [a] relevant sense. A person with more wealth has greater opportunity to set up a business, to purchase further and higher education, to undertake unpaid internships so as to get a first step into an area of work, or to travel and make connections and gain inspiration, and so on.

(White 2018, 170)

This does seem to be somewhat contrary to justice.

There is a possible structural injustice here, too. Accumulations of wealth over the generations may, as Rawls indicates, "be inimical to background justice, for example, to the fair value of the political liberties and to fair equality of opportunity" (Rawls 2003, 161). The conditions in which agents interact

may be free and fair at an earlier time, [but] the accumulated results of many separate and ostensibly fair agreements are likely in the course of time to alter citizens' relationships so that the conditions for free and fair agreements no longer hold. (Rawls 2005, 266)

Not only may the benefits of inherited wealth be unjust in their own right: they may skew the social conditions under which agents' relationships with one another play out.

Hence we would appear to have reason to think that justice may be served by legislating for policies that would minimise what a person could bequeath or inherit. One option would be to increase the amount that can be claimed by the state in the form of a confiscatory inheritance tax. As White puts it,

if inheritance is correlated with other advantages, inheritance tax can be seen as a way of neutralizing inequality in wealth inheritances so as to secure greater equality of opportunity. (White 2018, 170)

Granted, this would not eliminate the benefits that the children of the wealthy would enjoy in terms of opportunities and resources; but it would perhaps make two 
differences. First, it would help to level out the advantages accruing to Smith and not to Jones that might arise from a bequest naming Smith. ${ }^{1}$ Equalisation per se may not always be desirable if we are simply levelling down; but, second, a confiscatory tax would provide a flow of money into the exchequer that could be put to use making good the difference between the opportunities available to Smith and Jones. For example, the money may fund public education, or a maintenance grant so that Jones would not have to spend her university years working in order to afford food and books - and she would have more time to pursue her projects to boot.

Real world politics might suggest that such arguments are not powerful; inheritance taxes are not popular. ("It is clear," notes a 2017 article in The Economist, "that antipathy to inheritance taxes is widely shared among politicians and their electorates." (Anon 2017)) Daniel Halliday states that Australia, Canada and New Zealand do not tax inheritance, while Sweden, "often viewed as a natural habitat for egalitarian ideas, taxed its last intergenerational wealth transfer around 2014"- but he is open to the possibility that "[s]uch trends probably represent an injustice in their own right" (Halliday 2018, 2-3). ${ }^{2}$ Why might reality be like this if the injustice of inherited wealth is so clear?

One possibility is that realpolitik and justice make for uneasy bedfellows; but this is to assume that the question of what is just has been settled. That is not so. While equality is an important consideration in respect of justice, it is not the only one; the argument for a confiscatory inheritance tax may run up against the idea that a just state would respect individuals' rights, too. Being able to dispose of property as one sees fit is a plausible part of ownership rights; and if there are certain rights at stake in inheritance, it might be that intuitively undesirable social outcomes are bullets we have to bite in order not to violate them. Bluntly, maybe inheritance is an expression of certain rights that we ought to respect.

In Anarchy, State, and Utopia, Nozick complains that discussions of distribution

tend to focus on whether people (should) have a right to inherit, rather on whether people (should) have a right to bequeath or on whether persons who have a right to hold also have a right to choose that others hold in their place. I lack a good explanation of why the usual theories of distributive justice are so receipt oriented; ignoring givers and transferrers and their rights is of a

\footnotetext{
1 One should note that Jones might be richer than Smith, and that the bequest might be written with the intention of raising Smith to something like Jones' level of wealth. In that case, inheritance tax may not neutralise inequality. However, as I shall argue later in the paper, it may be that a just society would not leave Smith needing an inheritance to make good the difference between him and Jones.

2 I take inheritance to be the paradigmatic "intergenerational wealth transfer". Halliday may be technically correct about the abolition of inheritance tax, but this disguises a range of in-practice ways in which estates may be taxed. For example, Canada has not had a statutory inheritance tax since 1972 . However, a person is deemed to have disposed of all capital assets and to have received the proceeds from that disposal immediately prior to death; these proceeds are then liable to capital gains tax. (See https:// www.canada.ca/en/revenue-agency/services/tax/individuals/life-events/what-when-someone-died/deeme d-disposition-property.html for details.) This is process fills the ecological niche that inheritance taxes might occupy in other jurisdictions. Either way, it leaves untouched the matter of principle surrounding the desirability or otherwise of inheritance taxes.
} 
piece with ignoring producers and their entitlements. But why is it all ignored?

(Nozick 1974, 168)

It is straightforward enough to construct a recognisably Nozickian account of the rights involved in inheritance. A version of the Wilt Chamberlain argument might be invoked to show how notionally unfair distributions may arise without violating anyone's rights-indeed, as a product of those rights (Nozick 1974, 160-164). However good and desirable equality are, we might say, individuals' rights to own and dispose of their goods as they see fit trumps them; and taxation of any sort nibbles away at this right. And though Nozick had concerns about the effects of wealth passing down the generations, suggesting that it was at least a moral problem worth considering (vide Nozick 1990, 30; I shall consider this aspect of his thinking later in the paper) maybe one could try to sooth them, and persuade Nozick to embrace naïve Nozickianism more wholeheartedly.

It is to the claim that there is a right, or a set of rights, involved in wills that should be respected that I shall turn my attention in the remainder of this paper. I shall focus on three questions. First: what approach would best substantiate intuitions about inheritance rights? Second: how well is that best approach reflected in current laws? Third: is the best approach persuasive, all things considered? For the sake of simplicity, I shall assume that all inheritance is "vertical", by which property passes down from one generation to another-usually to offspring or grandchildren. I shall argue that there is a way to make sense of rights when it comes to questions of inheritance, and that it does provide us with a lens through which we can examine real-world laws, but also that the rights-based arguments for inheritance are not all that persuasive all things considered. Hence there is, at least in principle, an argument available for a confiscatory inheritance tax. The rate at which that should be set is a question for further work that is beyond the scope of this paper.

\section{Choice and Wills}

There are at least two ways in which one might parse a phrase like "inheritance rights"; the quotation from Nozick a little while ago anticipates the distinction I am about to draw. We could be talking about rights of bequest, in which case we would be asking about the nature and scope of a person's right to bequeath as he sees fit; or we could be talking about rights to inherit. On top of that, there is a familiar convention according to which a natural right may be classified as being based either in interest or in choice. Let $\varphi$ stand for some action or commodity. On the former account, an agent has a right to $\varphi$ to the extent that $\varphi$ serves the right kind of interest in the right kind of way. On the latter, which is somewhat more straightforward, a right describes something that an agent may take or leave as she chooses. To paraphrase Hart, she has a right to $\varphi$ to the extent that she either has no duty to refrain from $\varphi$, or is in a in a position to determine by her choice how some other agent ought to behave in respect of $\varphi$ (Hart 1955, 179-180; 1982, 184).

This suggests a framework by which we can analyse the putative rights in question: we can ask whether there is a choice-right to bequeath, or an interest-right; 
and we can ask whether there is a choice-right to inherit, or an interest-right. And the answers that we generate to these questions would provide us with a means by which we could test the conformity of this or that legal system with our rights.

So, then: how might we make out an argument for a choice-right to bequeath? If it's merely a matter of making a statement about what should happen to certain property after the testator dies, then the right seems to be fairly thin: anyone can make, or decline to make, any such statement. This would tell us precious little about why that statement should be considered to have any normative heft, because it rests on a threadbare representation of bequest. The putative right to bequeath implies something richer, indicating a choice that some other person be given title over some property. However, that seems also to bring perplexities, since it is not clear how $I$ could have a right that you obtain something. For sure, choice theory makes it easy to say that I can relinquish my possession of a good-if I have a right to ownership, and rights are alienable in the way that choice theory implies, then part of a right to own something is the ability to stop owning it. But it would appear that there is an extra step needed to explain how that good becomes yours as a matter of $m y$ right.

Perhaps we would want to say that making a bequest is a bit like giving a gift, and understanding gifts would help us understand bequests. In giving a gift, I choose to waive one person's duty, which still binds everyone else, to refrain from claiming some $\varphi$, and also — to distinguish a gift from a willingness to share-waive my rights over it. But the problem here is that a bequest is a paradigmatic instance of my not relinquishing ownership of something: it only gains currency after my demise, at which point I would presumably not be capable of owning anything, or choosing anything about it, anyway. ${ }^{3}$ Hillel Steiner makes a related point:

Testators, unlike donors, incur no duty not to interfere with the recipient's possession of the object whose ownership is transferred. Presumably, it's precisely in order to avoid incurring such a duty that persons choose to transfer things by bequest rather than by gift. (Steiner 1994, 254)

Maybe a bequest could and should be treated as a kind of promise, so that in making a bequest one imposes on oneself, through choice, a kind of duty. Others would then have a right to inherit as the "footprint" of this choice. Yet this doesn't seem quite right, because promises are supposed to be binding in a way that wills aren't: if I've promised you something and change my mind the following day, we might still think that I have a moral duty to do what I had promised. If I insert a clause into my will that I alter the next day, nothing seems to be open to the same moral complaint; so there does not seem to be a duty there after all, which counts against bequests being promises. ${ }^{4}$ Moreover, the promise model would likely fail as a justification for the status of wills in law, since promises do not generally have any particular legal gravity, at least insofar as that statutes are not written about what one may promise to

\footnotetext{
${ }^{3}$ It is notable on this point that Hart bases his choice theory of rights in a claim about liberty; but the dead have no liberty.

${ }^{4}$ Between submitting this paper to the journal and its acceptance, I discovered that Cécile Fabre mounted very similar arguments to these in her response to Steiner (Fabre 2001, passim).
} 
whom, about their enforceability, and about third parties' rights to dispute a promise. Of course, we might move then to say that some promises do have this legal weight: these are the promises we call contracts. But one loses at least as much as one gains by making this move, because a "contract" that might be drawn up without the knowledge of one of the contractors and that can be abandoned on a whim, as is the case with wills, is so strange a beast that it must surely belong in a different cage.

In short, it is not easy to see how a right to bequeath can really be explained in terms of choice theory. The straightforward alternative is to try to explain it as an interest right. How might this argument look?

\section{Interest and Wills}

The simplest way to try to explain rights to bequeath in terms of interest would likely try to tie it to an interest in owning property. Very loosely, being able to dispose of things as I see fit is a part of owning them, and with having control over my own life and the form that it takes. I have an interest in controlling my life to the greatest extent possible, and being able to dispose of property is a part of that. Conversely, not to be able to transfer title over some item would fly in the face of the freedom to run my own life.

Clearly, this kind of account runs up against versions of the objections posed against choice-theoretical accounts, not the least of which is that though I might be able to make out a right to make a will, it is not yet clear that I would have any right for that will to be seen as binding by or on anyone else after I am dead. But it runs up also against a further concern, which is that it is straightforward enough to say that I may dispose of my goods insofar as that I have an interest in running my life as I see fit, but quite another to say that this extends beyond my death, when there is plainly no life left then for me to run. On the other hand, it may be possible to construct a theory that allows us to make sense of post-mortal interests. If one may have post-mortal interests, and if those interests could ground rights, we would have a chance of filling the normative gap.

One account of post-mortal, or "surviving", interests is offered by Joel Feinberg. These may be self- or other-regarding, though they are perhaps illustrated most easily by an appeal to the self-regarding interest I have in my good reputation. That interest is clearly salient while I am among the living, and it is important to note that I do not have to know about my reputation's being tarnished still to have an interest in its not being tarnished. However, since the reputation in which I have an interest will survive me, and given that I don't have to know about the tarnish for it to be against my interests, it's not clear at all that my interest in maintaining my reputation must die with me (Feinberg 1987, 87). This ought to be enough to show that there is at least one interest that one may have post-mortally. If we agree that one may have interests that can be thwarted despite one's ignorance while alive, as when people besmirch my reputation without my knowledge, and if it is unclear why having died should make a difference, then it must be that one could have interests that can be thwarted while dead. 
Implicitly, a certain allocation of goods after my death might serve my persisting interests. Feinberg offers a scenario highly relevant to my concerns here:

$[\mathrm{M}] \mathrm{y}$ other-regarding interest in the well-being of my children could be defeated or harmed after my death by other parties overturning my will, or by thieves and swindlers who cheat my heirs of their inheritance. None of these events will embarrass or distress me, since dead men can have no feelings; but all of them can harm my interests by forcing nonfulfillment of goals in which I had placed a great stake. (Feinberg 1987, 87)

If I have an interest in my children's flourishing that motivates me to bequeath goods to them, their not being able to inherit those goods counters my interest. Feinberg's concern is with the harm that may arise from such situations-

[t]he antemortem person was harmed in being the subject of interests that were going to be defeated whether he knew it or not. It does not become "retroactively true" that as the subject of doomed interests he is in a harmed state; rather it was true all along (Feinberg 1987, 91)

- but we could easily recast things in terms of rights. If I have an interest in my property being distributed like so, then this may ground a right that it be. If that interest is thwarted, any concomitant right will have been violated. Indeed, this kind of line may strike us as being stronger than Feinberg's own formulation, inasmuch as that we may have lingering doubts about whether the dead can be harmed, or whether accounts of harm are our own projection. However we frame things, though, what matters is that a Feinbergian account may offer us a way to argue that there are at least some interests that persist beyond the demise of the person whose interests they are; and if one thinks that rights are based in interests, it is at least possible to argue from this sort of starting point that an interest in one's estate being distributed in such and such a way could yield a right to bequeath.

A different way to get to much the same point might be derived from Dworkin's distinction between experiential and critical interests. Experiential interests are based on our current desires. Critical interests are not: they provide the buildingblocks of what an agent may consider a good life, but they might not be immediately clear to us. As such, they might be things we discover, rather than assert, about ourselves (Dworkin 1995, 201-206 and passim). Dworkin offers dignity and integrity as paradigmatic examples of critical interests: they do not contribute to our everyday experience or enjoyment of life, but they are components of a good life; moreover, others have a reason to take notice of dignity and integrity as a part of taking us seriously as agents. Importantly, since critical interests are not experiential, they may persist even when one has no presently-occurring preferences. For example, a patient in a hospital who is unconscious, and who is never going to regain consciousness, will have no experiential interests in what happens to him. Nevertheless, decisions may still be made about what is in his interests: we might think that there are certain procedures to which he has a right not to be subjected for the sake of preserving the dignity in which he has a critical interest. 
To be concerned about this sort of thing is to take him seriously as a person. Such concerns about dignity extend after death, too: there are things that we would not accept being done to a corpse because it is undignified, though it is clear that the corpse wouldn't mind.

If there is at least one critical interest that can stretch beyond the preferences that one has at a given moment, the door is open to thinking that there could be others. Importantly, this kind of account might give us an insight into the apparent moral importance of things like funeral arrangements and-of more direct relevance to my concerns here-wills and bequests. To honour instructions of this sort is to take the person who made them seriously, just as to be concerned about dignity is to take the person seriously; and this is to act in his best (critical) interest. Should a person have a strong preference for burial over cremation, our reasons for respecting that could be cashed out in terms of his critical interest in exercising control over what happens to his remains. And should Aunt Mabel have a preference for distributing her estate in a certain way, our reasons for respecting that could be cashed out in terms of her critical interest in exercising control over what happens to her things. Insofar as that lawmakers have a reason to ensure that law tracks morality, this moral importance may be the sort of thing we'd expect to see reflected in statute.

Admittedly, it is harder for this account than it is for Feinberg's to make sense of the idea that the dead have interests in their own right. If we decided to ignore the requests of a person since deceased, Dworkin offers no clear mechanism to say that their lives would be in any way less good. But an appeal to critical interests doesn't work-or, at least, doesn't have to work-in this way. We could defend it by means of an appeal to the living.

Suppose that we had a policy of paying no regard to people's instructions about what should happen to their bodies or estates, and their preferences therefore made no difference to our actions. This would be in tension with taking them seriously as agents now - it's hard to see how one could claim to have high regard for a person while having none at all for the kinds of thing he wants-and not just those agents, but people generally. But we have a moral reason to treat people seriously as agents, from which it would seem to follow that we have a reason to take their preferences seriously. This does not depend on any account of persisting interests: it is enough that it is in the interests of presently-living people to do so. In effect, we have a reason to treat people's instructions as having at least some kind of persistence, even if this is a noble lie, for the sake of the living's interests in being taken seriously. We take Smith's desires seriously on behalf of Jones, Brown, and Robinson. Applied to the case of bequests, we take the distribution of goods in a will seriously as a way of taking persons seriously. We allow Aunt Mabel's desires about what happens to her property to hold sway even though she is dead not because we are concerned about her, but because they were her desires, and taking desires seriously is part of a desirable general stance towards persons.

Hence, I contend, if there is a right to bequeath, it is more likely that it could be successfully explained by a kind of interest theory than by a choice theory. What this does not mean is that a person's expressed desires are trumps, or that establishing that some action serves an agent's interests means that he has a right to it. In some circumstances, we can take someone's wishes and preferences seriously, and as a 
component part of taking them seriously, without doing what they wish and prefer. If someone has died from anthrax, this may make a difference to how we dispose of the body, irrespective of their preferences. Correspondingly, even if we can establish that it is in someone's interests to be able to bequeath, or that they have a persisting interest in that bequest being adhered to, it does not follow that there can be no conflicting considerations such as others' interests or justice. But the onus would be on the critic to show why a putative interest-based right to bequeath is prima facie and rebuttable. I shall return to this in a few pages' time.

\section{Rights to Inherit}

In the meantime, what of the putative right to inherit? If there is a moral right to inherit, we would be able to say that legal traditions that do not recognise that right are pro tanto morally defective, and that legal systems that do require that a certain proportion of one's goods should be left to certain specified people may have virtue on their side, provided that the property in question is funnelled to the right people. Again, we can try to give an account either by appealing to choices or interests.

A choice theory of inheritance would say that we have a right to inherit insofar as we are free to accept a bequest. On the face of it, this looks fairly straightforward: if Aunt Mabel tells me that she intends to leave her china dogs to me because I'm her favourite, I can tell her that she doesn't have to, or that I would prefer she didn't. So far, so good: the correlate of being able to accept a bequest is that one can refuse it, and there ought to be no difficulty in a legal system accommodating such refusal. However, it should be noted that what we've described is simply a negative right-a right not to inherit-rather than a positive right to inherit, and it is not easy to see how one might base a positive right to inherit in any choice of the beneficiary. A right to refuse a bequest no more implies that one has a right to be a beneficiary than a right to refuse a slice of cake once offered implies that one has a right to be offered it. Choice theory does not appear to generate a right to inherit.

We can avoid these problems if we treat inheritance as being a right inasmuch as that it serves a morally relevant interest. On this account, if Alice stands in moral relation to Bob in the right sort of way, and if she has an interest of the appropriate sort in inheriting some portion of his property, then we would be in a position to say that she has a right to do so, and that a legal system ought to recognise that right. This would be a positive right — we would be talking about a fully-fledged right to inherit rather than a mere right not to-and so Alice would have grounds to press that right against Bob's estate. What counts as the right sort of interest and the right sort of relationship would require elaboration; but the framework of the argument seems to be robust as far as it goes: since it is usually in one's interest to have more stuff than less, it would follow that inheriting stuff usually is in one's interest. (As a counterpoint, Rabelais suggests that being in debt may be desirable: "Always owe somebody something," says Panurge in The Third Book of Pantagruel, so that "he will be forever praying God to grant you a good, long, and blessèd life" lest he never recover what was owed (Rabelais 2006, 422-423). If that's right, inheriting Bob's debt may be in Alice's interests too. But Rabelais is joking.) 
Finally, there may be a shared interest between testator and inheritor. Nozick suggests that bequest

is an expression of caring about [others], and it intensifies those bonds. It also marks, and perhaps creates, an extended identity. The receivers-children, grandchildren, friends, or whoever-need not have earned what they receive. Although to some extent they may have earned the continuing affection of the bequeather, it is the donor who has earned the right to mark and serve her relational bonds by bequeathal. (Nozick 1990, 30)

If emotional bonds between people are in those people's interests-as surely they are-and if bequest is a way of representing and deepening those bonds, then it may well be that we could mount a claim that bequest serves their interests. And this, in turn, might lend weight to the idea that the law ought to recognise a right to bequeath and to inherit, just because this right is, at the very least, an indication of something important.

In other words, there seems to be a way to make out an argument for both a right to bequeath and a right to inherit based in an appeal to the interests of both the testator and the beneficiary; and, working the other way, if there is a right to bequeath or to inherit, it must be based in interests rather than in choice. This is enough, I think, to provide us with a lens by which we can examine real-world legal systems. How well do they respect this kind of right?

\section{Inheritance Rights in English Law}

As far as English law is concerned, individuals drawing up a will may decide who gets what as they see fit. I can make anyone my beneficiary, and I can disinherit them if I take against them. (One source reports that the author and traveller Edward Wortley Montagu was disinherited by his father "for excesses including sporting buckles and buttons worth $£ 2500$, wearing a wire wig, becoming a Mohammedan, marrying first a lady of easy virtue and then a Nubian, and having to run to escape jail in Paris" (Watson 1960, 70 (slightly modified).) In this way, the rights are held, at least for the most part, by the testator. There is some scope for wills to be contested in the event that the testator lacked capacity or was unduly influenced when the will was drawn up, or if there has been committed one of a handful of errors in the administration of the will. ${ }^{5}$ Still: when wills are contested, the onus is on the claimant to show that something has gone awry-in other words, that we have a positive reason to disregard the will as written. However, inheriting anything under this arrangement is by and large a privilege rather than a right; and provisions about testators lacking capacity or being unduly influenced look to be concerned with

\footnotetext{
5 The criteria for the validity of a will are set out in s.9 of the Wills Act 1837, as amended by s.17 of the Administration of Justice Act 1982. The capacity criterion is articulated in Banks v Goodfellow [1870] LR 5 QB, per Cockburn CJ; and a good example of undue influence being used to set aside a will can be found in Edwards v Edwards [2007] EWHC 1119 (Ch).
} 
maintaining the testator's rights. If Aunt Mabel chooses to leave her collection of china dogs to me, that's fine. If she leaves it to her children, or to the cats' home, or if she stipulates that it be thrown into the sea, then that's fine as well. Neither I, nor her children, nor the cats, have any enforceable right to any part of her estate; if there is a right to inherit, it is wholly parasitic on Mabel's right to bequeath. If there are interests served by inheritance rights, they are the interests of the testator.

There is a qualification to this. As Lord Hughes confirmed in the Supreme Court in Ilott (Respondent) $v$ The Blue Cross and others (Appellants) ([2017] UKSC 17 at 1), English law knows no rule of forced heirship-forced heirs being those people whom the law gives a right to inherit that takes priority over the testator's wishes. Nevertheless, certain people may apply to the courts under the terms of Section 1 of the Inheritance (Provision for Family and Dependants) Act 1975 to contest a will that "is not such as to make reasonable financial provision". Under Section 2 of that Act, the court is given the right to make one of a range of orders including lump sum payments from the estate, periodical payments, or transfer of ownership. ${ }^{6}$ Thus in the case of Thompson $v$ Ragget, in which a Ms. Thompson was written out of the will of Wynford Hodge, her deceased partner of 42 years, Jarman J noted that she had been "financially dependent upon him throughout that time and at his death", and that she had "very modest savings", ruling in the end that she was entitled to support from his estate to the value of several tens of thousands of pounds ([2018] EWHC 688 (Ch)). In Nahajec v Fowle, it was ruled that the testator had not made reasonable provision for his daughter, even though they were estranged and had seen little of each other for 18 years ([2017] EW Misc 11 CC). This does seem to indicate that there is at least some regard for the interests of beneficiaries and would-be beneficiaries in English law, however subordinate they may be, and that this does give the glimmer of a right to inherit under some circumstances.

In the event of someone dying intestate, there are procedures in English law that determine how property should be distributed; part IV of the Administration of Estates Act (1925) sets out who should inherit what when someone dies without leaving a will, listing the family members to whom property should pass and the circumstances in which it should pass to them. The primary concern is with the deceased's spouse, offspring, and/or parents. It is tempting to treat this as a right to inherit, again based in an appeal to their interests. However, this right is not "bankable": it comes into effect only if the deceased has not given instructions, and the relatives in question have no standing to dispute a valid will. Hence-again-the general convention under English law is that there is a right to bequeath, but at most a much more limited right to inherit; whatever nuances and qualifications there may be to this serve to illustrate the principle that exceptio probat regulam in casibus non exceptis.

(In this light, we might also consider Riggs $v$ Palmer, the case famously considered by Ronald Dworkin in Taking Rights Seriously (Dworkin 1997, passim).

\footnotetext{
${ }^{6}$ Interestingly, under s. 2(1) of the Act, at least as it's reproduced on http://www.legislation.gov.uk/ ukpga/1975/63/section/2, subsection (h) is listed before subsection (g), possibly because it's good to keep people on their toes.
} 
Obviously, an English law from 36 years later has no bearing on that case-but it is not unreasonable to think, based perhaps on a touch of Dworkinian constructive interpretation, the cultural similarity of England and the US, and the shared ancestry of the two legal systems, that the norms that informed the American case may also have informed Parliament in 1925. In Riggs v Palmer, it was decided that there was no ground on which Elmer Palmer could inherit according to the otherwise valid terms of the will of Francis Palmer, the man he killed in order to secure that inheritance (115 N.Y. 506 (1889), at 514-5). The proper next step would simply be to distribute Francis' estate along the lines set out in the remainder of his known desires; had there been no indication of how he preferred his property to be distributed, he would presumably have been treated as having died intestate, and his remaining relatives would have inherited his property according to the accepted conventions of the day. The important point is this: the Court ruled not that Mrs. Riggs and Mrs. Preston, the claimants in the action, had a right to inherit despite the terms of the will, but that, because of Elmer's perfidy, "the devise and bequest in the will to Elmer be declared ineffective to pass the title to him". Had Francis died in his sleep, Elmer would have inherited, no matter how much others may have grumbled. They would not have been able to insist that the will should be overturned because it contravened any legal mandate from the get-go.)

What this means is that English law recognises rights to bequeath, while putative moral rights to inherit can, in many cases, be legally ignored, particularly if the would-be beneficiary is not in need of support from the deceased's estate. If we think that the putative moral right to inherit is compelling, though, English law looks to be defective.

\section{Inheritance Rights Elsewhere}

Other legal systems work in the other direction, circumscribing certain rights of bequest and granting something much more like a right to inherit. Rather than working my way through every legal system that is neither England's nor one of her daughters', I shall take French law and the Sharia tradition as my exemplars.

In France, the Code Napoléon specified that "free gifts" in a will were limited according to the number of legitimate children left by the testator-the more of them, the smaller the part of his estate that could be disposed of at his discretionand that children could not be disinherited. Here, if there are rights, they are rights against the testator held by the children rather than rights held by the testator. In this, it modified the principle set out in the Revolutionary Loi de Nivôse an II, which imposed strict equality between heirs, and allowed the testator discretion over only one tenth of his estate. That tenth, notably, was required to go outside the immediate family, in order to prevent the accumulation of wealth within a family unit: arguably, in a point that will be important later in this paper, the interests to be served here were those of wider society (Boring 2015).

Current French law distinguishes between the "reserved portion" and the "disposable portion" of an estate, such that 
[t]he reserved portion is that part of the assets and rights of the succession whose devolution, free of charges, legislation assures to certain heirs, called forced heirs, if they are called to the succession and if they accept.

The disposable portion is that part of the assets and rights of the succession that is not reserved by legislation and of which the deceased can freely dispose by liberalities. (Civil Code, Art 912)

In respect of the disposable portion, it stipulates that

[1]iberalities, either by inter vivos act or by testament, may not exceed one-half of the property of a disposing party, if he leaves only one child at his death; one-third, if he leaves two children; one-fourth, if he leaves three or more. (Civil Code, art 913)

Subsequent clauses make provision for other relatives (Civil Code, Art 914). The basic picture is that a specified proportion of an estate is left to the deceased's forced heirs; the remainder can be bequeathed according to the deceased's taste, but its value will plainly fluctuate according to the number of heirs (Goré 2012, 295). Hence heirs are protected from what the Civil Code calls "liberalities" (Civil Code, Art 913 and passim). Further, "[i]n any inter vivos or testamentary disposition, the conditions that are impossible or are contrary to legislation or good morals, shall be deemed unwritten" (Civil Code, Art 900). What matters here is that patters of inheritance are marked less by rights of the testator, as duties; what rights there are lie primarily with the beneficiary. If Aunt Mabel happened to die under French law, she would have free rights of disposal over only a portion of her estate.

In a similar way, the Koran, which is the bedrock of the Sharia tradition, specifies a number of rules governing inheritance. For example, in sura IV, it is stipulated that

[a] male shall inherit twice as much as a female. If there be more than two girls, they shall have two-thirds of the inheritance; but if there be one only, she shall inherit the half. Parents shall inherit a sixth each, if the deceased have a child; but if he leave no child and his parents be heirs, his mother shall have a third. If he have brothers, his mother shall have a sixth after payment of any legacy he may have bequeathed or any debt he may have owed.

I am not too concerned here to trace the particular intricacies of who can inherit what; suffice it to say that, in this tradition, there is an expectation that certain people have what amounts to a right to inherit what is left of any estate once debts are paid; and the content that legacies may take once debts are settled is influenced by the specification that "those of you that leave property shall bequeath it equitably to parents and kindred" (Koran 1994, ss 4:10; 2:180).

What both these examples establish is the that there are legal systems that set out requirements concerning inheritance that a will must satisfy. In both the cases outlined, some specified survivors of the deceased have a right to inherit. If this legal right is taken to reflect a moral right, then we can best make sense of this by interpreting it as being based in beneficiaries' interests. And, of course, we may be able to say by the same token that the Jacobin law from an II, which forced property out of the family, was morally questionable. 
An appeal to beneficiaries' interests and the rights that spring therefrom can also help examine and assess how legal systems deal with intestacy. As we have seen, in England, under the terms of the 1925 Act, property devolves to the next of kin in cases of intestacy; and it is reasonable to expect that intestacy would be even less of a problem under legal systems where family members have rights to inherit as a matter of course.

\section{Keeping it in the Family}

One characteristic common to all the legal systems I have mentioned is that they have a special place for family members when it comes to deciding what to do with the property of the dead. This is most explicit in the French and Islamic traditions, under which certain family members are given a specific protected status, sufficient to grant certain people a right to inherit that overpowers any putative right to bequeath as one wills. Under the English tradition, where there is no distinctly stated right to inherit, the family generally fills the gap when someone dies intestate. Section 46(1) of the 1925 Act outlines the order of priority by which property devolves to relatives, with the deceased's spouse being first in line, followed by his or her offspring, parents, grandparents, and aunts and uncles. So, again, family (or, at least, reasonably close family) is given a position in law that others do not enjoy. Should someone die intestate with no known heirs of requisite proximity, that section of the Act dictates that

the residuary estate of the intestate shall belong to the Crown or to the Duchy of Lancaster or to the Duke of Cornwall for the time being, as the case may be, as bona vacantia, and in lieu of any right to escheat

and continues to say that

[t]he Crown or the said Duchy or the said Duke may (without prejudice to the powers reserved by section nine of the Civil List Act, 1910, or any other powers), out of the whole or any part of the property devolving on them respectively, provide, in accordance with the existing practice, for dependants, whether kindred or not, of the intestate, and other persons for whom the intestate might reasonably have been expected to make provision. (Administration of Estates Act 1925, s. 46(1)(vi))

This latter point is particularly interesting. By telling us that mere cousins have as little claim on the estate as any other member of the public, it confirms the elevated status of closer family members. Put another way, it makes clear that if I had been dependent on Mabel but was only her $n$th cousin, the Crown or relevant Duchy may-but not must-provide for me. If an appeal to interests is what motivates inheritance rights claims, then whose interests and rights they are clearly matters.

One reasonably plausible explanation for the content of the law is that laws that privilege certain familial relationships are justifiable in terms of the desirability of avoiding destitution. In all likelihood, the argument would be something like this: 
people have a right not to be left destitute, which would be more of a risk if they did not have some claim on the property of the deceased. Indeed, it might be that it is a serious wrong for me not to make provision for my dependents - serious enough to warrant legal intervention. We might be able to push the argument further in order to generate a case for some kind of forced heirship. What we might still want to know, though, is why blood relatives should be given a privileged position: after all, there is no obvious reason why the interests of close blood relatives are of more moral weight than those of people who are less closely related but perhaps no less dependent. On this front at least, English law's insistences that a will can be disputed on grounds of reasonable provision seems to be morally laudable. (I shall return to the question of the status of family members in a little while.)

Admittedly, rights arising from beneficiaries' interests may not be the only way we can explain the way that legal systems administer estates, whether or not there is a will. The community's interests may also be a consideration. For example, it is not desirable within a polity to have people destitute; but it is possible that at least sometimes people would be left destitute by virtue of a relative being intestate, or having been persuaded to leave all his goods to the unctuous neighbour, or something like that. Thus legal systems may seek to ameliorate the social problems arising from particular people's possible destitution by allowing dependents to dispute a willeven English law appears to allow for this - or by insisting that a certain percentage be left to certain people from the get-go. Seen this way, law would behave in much the same way as it would if the beneficiaries' interests were the motivating factor, although their interests would actually be considered only insofar as that they are a component of the community's interests. However, in such cases, it would be less that I have a moral right to inherit than that I have a civil one. Presumably, this could be rescinded.

Alternatively, it might be held that it is desirable that certain property be kept in the family. Inheritance of, say, farmland might be endorsed in order to incentivise the kind of improvement of the land that may take generations. Having said that, in situations such as this, we may find that we are once again talking less about thoroughgoing moral rights to inherit that should be recognised by law as something more akin to a permission to inherit that is generated by law, or even a kind of duty to inherit—and anyway, as Halliday points out, "[i]n many regions where the inheritance tax debate has substance, the family farm is becoming a bit of a myth" (Halliday 2018, 170); where it is companies that do what family firms used to do, arguments for preserving inheritance that draw on this kind of consideration weaken.

\section{Comparing Interests}

All the same, showing how a set of legal provisions for inheritance might be justified is not the same as showing that they are justified, all things considered. Are they? In this section, I shall argue that they are not. My argument has five elements: first, that whatever interest heirs or relevant dependents have in inheritance may easily be matched by the interests of strangers; second, that it is not fair that heirs' (forced or otherwise) needs get priority over others' needs; third, that there is no need in 
modern societies to rely on inheritance to satisfy putative heirs' needs, not least because inheritance is not a particularly good way of satisfying them to begin with anyway, either-fourth-economically or-fifth-morally. None of these elements ought to be too hard to swallow.

The first two stages of the argument require only a very little elaboration. If we allow that a person has an interest in inheriting from an estate, and that this is morally important, it seems straightforward enough to point out that there will be plenty of others who would benefit from that same estate, and so have an interest in inheritance. More widely, the community as a whole may well benefit from getting at least a share of the assets. While my interests - and we can allow that they are worth taking morally seriously - might be served by inheriting from Aunt Mabel, others have a comparable interest. Whatever needs I have are likely to be mirrored by at least some other people; and even if my needs are sui generis, the community as a whole has needs of its own, which we might be in a better position to serve if we could liquidate Aunt Mabel's estate. Bluntly, there is a moral reason to allow the state to seize her property and to sell it off to whomever will take it. This will help fund public services, reduce house-prices by increasing supply, and so on. This, even if not compelling in the end, probably ought to be taken seriously. So much for element one of the argument.

The second element is elaborated even more quickly. We have already seen how patterns of inheritance may distort the circumstances of justice. My inheriting Aunt Mabel's assets gives me an advantage that others lack, with the associated social benefits. In most cases, inherited assets are not "earned"; therefore I am benefitting from serendipity in a manner that is not only unfair, but also unjust. Moreover, if inequality is undesirable in itself, and the effects of inequality also undesirable, it would seem to follow that the community sensu lato would have an interest in there being less inequality. Thus if (a) other members of the community have an interest in there being less inequality, and (b) inheritance is something that feeds inequality, there would be the opportunity to say that we ought not to support laws that formalise it. The point common to the first and second elements of the argument is that, if interests are providing the moral motor for our arguments in defence of inheritance rights, it looks as though that motor may backfire to at least some degree by providing people who would not otherwise inherit with a bankable right to benefit from an estate.

The third element of the argument rests on the claim that there is no need for inheritance in modern societies to meet putative heirs' legitimate interests. Allow, arguendo, that it is wrong to make no provision for a certain group of people (dependents, family members, or something like that) after one's death in circumstances in which it is reasonably foreseeable that this will leave them destitute. A lot is riding on what we may reasonably foresee. The risk of destitution is high in some parts of the world, and has been high everywhere for most of history. To have a legal system designed to minimise the chance of destitution would seem to be morally desirable, and therefore might have stood a fighting chance of justifying inheritance for the bulk of human history. But_and this makes a difference-while there was nothing like a comprehensive welfare state in post-Classical Arabia (per the Islamic tradition) or in Enlightenment Europe (per the civil code origins of the French law), 
and there probably could not have been, it is possible today. That possibility ought to guarantee that no one would be left destitute without an inheritance. In fact, one of the functions and justifications of the state is that it can ensure that no one is left destitute; and a state that has the capacity to ensure that no one is left destitute but that does not pursue policies that make use of that capacity is arguably to that extent unjust. If an adequate welfare system exists, then nobody should be reliant on inheritance to avoid destitution. Hence the idea that inheritance can serve as prophylaxis against destitution in a modern, functional state seems to lack heft. ${ }^{7}$

For sure, some modern states may be unable to provide adequate welfare for their people; others may be able but_-for reasons best known to the electorate- unwilling. In such cases, we may have to admit that there is a reason to support inheritance, based in an appeal to the interests of people who may be left destitute otherwise. After all, it's probably better that some people's interest be served than that none be. But that can only take us so far. Legislating for inheritance rights in order to make good the insufficiency of social support is to admit that available social support is not good enough, and so much the worse for the children of the worst off. This is hardly a ringing endorsement of the institution of bequests. Working the other way, the kind of social safety net that it is reasonable to want to see in an admirable society — or even a decent society — would obviate any pressing need for inheritance ab initio. ${ }^{8}$ Of course, some people might not be as well off under such a dispensation as they otherwise could have been; but so long as they are at least well enough off, the idea that they have been wronged would be hard to sustain without presupposing a right to inherit. And this brings me to the next elements of the argument, between which there is significant overlap: arguing in defence of inheritance in states that do not or cannot protect the interests of putative beneficiaries is likely to come a cropper by dint of the fact that inheritance is not a good way to protect the most urgent interests anyway, either economically or morally.

The most obvious point here is that, if inheritance is intended to be our primary bulwark against destitution, it often isn't a very convincing one. This is straightforwardly shown when we consider forced heirship systems. The most that inheritance can offer to do in respect of destitution under this kind of dispensation is to stave it off from those who come from a reasonably well-heeled background already. And since those who come from such a background are less likely than those born into poverty to face destitution, the safety-net of inheritance will likely turn out to be most useful when deployed on behalf of those who need it least. As such, inheritance is potentially rather economically irrational, not to say-simply because it serves to protect the children of the wealthy more than the children of the poorunjust. In fact, it might bake in inequality.

\footnotetext{
${ }^{7}$ It might be thought that a system of inheritance allows the living peace of mind about how their offspring will fare in future. However, a robust system of social support will provide this peace of mind, too, and will do so in a way that provides as much peace of mind to the poor as to the wealthy.

8 One possible interjection here is that allowing people to bequeath wealth incentivises their having generated it in the first place, which may be beneficial for all. However, this would amount to saying that a just state has a reason to act as though there is a right to bequeath, rather than showing that there actually is a free-standing moral right that a just state ought to recognise.
} 
Insofar as that English law does not specify proportions that have to be left to certain people, it perhaps does not have to face down this particular objection quite as urgently as the French and Koranic systems, or systems that behave in a comparable way. The accommodation it makes for dependence at least opens the way for those who genuinely would face destitution to get their voices heard when an estate is administered. On the other hand, even this provision depends on the needy having the good fortune to be tied (a) in the right way to someone who (b) is wealthy and (c) dies at the right time. Most of the truly needy are not in that position: it's worth noting that the needy do not have anything like the same rights if the person on whom they're notionally dependent is currently either in rude health-in which case, inheritance is not the cure for their current needs-or not much better off herself-in which case there'll be little to nothing to inherit anyway. Moreover, there is a special place reserved for close family members in cases of intestacy irrespective of their need; it is up to those facing destitution to show that they should receive more.

Whichever way we pare things, the point would stand that laws guaranteeing any kind of inheritance right are likely simply to ensure that wealth stays with those who are already fortune-favoured. One needs only to glance at a nineteenth-century novel from Austen to Zola to see the mechanism of this kind of worry played out. (The Jacobin stipulation that one-tenth of the value of an estate should leave the immediate family is a slight mitigation of the problem, but only slight.) If there is an interest in not being destitute that the law ought to serve, it is not at all clear why the destitution or otherwise of family members - much less the interests of non-destitute family members-should weigh more heavily than the destitution of strangers.

So the economic and the moral defences of a legally-sanctioned right to inherit seem to be either rebuttable or to meet substantial counterpoints: such a right serves the interests of those whose needs are likely to be least pressing, while doing nothing to serve the interests of those whose needs are most pressing. At the same time, and thereby, inequality is allowed to pass down the generations. To the extent that inheritance rights are supposed to reflect rights based in certain interests, the interest that Smith has in inheriting seems to be matched Jones', and it is not clear why Smith should benefit from having wealthy patrons or family members. Smith may have a right to inherit what he needs; but this doesn't imply a right to inherit more than he needs, since his interest in possessing that extra amount would have to be balanced with Jones' interest in acquiring some share of it. More, if the state can ensure adequate welfare and opportunities for all, Smith turns out not to need very much from the estate to begin with. Finally, Jones (and possibly Smith as well on some accounts, though I shall not explore them here) has an interest in greater equality for its own sake. Hence it may turn out that the state would be justified in taking some, or all, of Smith's patron's estate and dividing it between Smith and Jones. In other words: a confiscatory and redistributive inheritance tax would seem to violate no rights based in an interest in welfare or equality, and it may serve them.

Strictly speaking, none of this sanctions state appropriation. We could recognise that people have a critical interest in distributing their fortune as they see fit and simply insist that they should be allowed to distribute it ad lib, so long as it is outside the family. (After all, if a legal system can define who is sufficiently close a 
relative to inherit, it can presumably define who is sufficiently close a relative not to.) In essence, we could mandate some form of post-mortem philanthropy.

Yet the problem here is fairly evident: even discounting the possibility that Aunt Mabel will leave her property to her friend on the nod-and-a-wink understanding that that friend will make an inter vivos gift of it to me, such a system may ensure that money leaves the family, but it may not be able to provide for the needy if their needs happen not to coincide with Aunt Mabel's preferences. Charitable gifts are unreliable ways of satisfying needs, and may do little more than reflect the donor's personality. One might think here of Mrs. Jellyby's works of "telescopic philanthropy" in Bleak House (Dickens 2003), or-less comically-of Saccard's support for the wildly opulent Work Foundation, which is based substantially in the pleasure he takes in "regulating this crazy dance of millions [of francs]", and not insubstantially in the prospect of his being recognised as "the king of charity, the god adored by masses of the poor" (Zola 2014, 44-45). There is no reason to suppose that charitable bequests would be any less shaped by folly and self-regard. Moreover, charity comes into its own, and is only really necessary, when the state is unable or unwilling to provide the services in question. The state, on the other hand, has the ability to require contributions and to distribute them not according to the tastes of donors or testators, but according to genuine need; and an inheritance tax would be one way to go about that.

A nagging doubt lingers, however, and it speaks to the notionally Nozickian claim that I mentioned at the start of this paper. Let's allow that inheritance laws do little or nothing to serve the interests of the neediest, and that there are interests that would be served by confiscation. Let's allow that these interests balance out rights to inherit or bequeath, so that whatever rights Smith has are matched by those that Jones has. All the same, there might be something that weighs in favour of Smith's inheriting property - a right that tips the balance, which serves as a side-constraint that we ought not to violate. It has to do with the interest we have in family ties.

Recall Nozick's point about the moral value of inheritance: that bequest marks and serves morally important bonds between people. For him, inheritance is a demonstration of a particular form of relationship with others that we do and should value, and is a guarantor of that relationship (Nozick 1990, 30). If this is correct, then we would seem to have a moral reason to take bequest morally seriously, whatever we think of the arguments considered over the preceding few paragraphs.

Still, we should not be convinced by Nozick's claim-indeed, we perhaps ought to be slightly repulsed by it. After all, the link that it draws between morally desirable ties between people and property is not all that attractive: although Nozick is not such a naï as to claim that inheritance is a necessary condition of expressing one's care for others, he does say that it can create and does intensify bonds between people. This does seem rather to imply that the bonds between people are stronger roughly thanks to the property that passes between them-which suggests that those with little or no property therefore don't have the same chance for such strong bonds. This is hardly plausible. Indeed, it would be strange to think that my bonds with Aunt Mabel are deepened in any morally important way because of the prospect of my getting the china dogs she promised to (or will inflict on) me. 
And this leads us to an important point: the morally important ties between people are not dependent on property. Property might represent a bond, but it is not a substitute for it; and not to have that property does not have any knock-on effects for that bond. It might be nice to own some item from a relative's estate, but the significance of my relationship with that relative does not depend on that item. I might be miffed to discover that I have been left out of a will; but this is a sign that I was mistaken about my relationship with the deceased, and it tells us nothing about rights to inherit or bequeath. Perhaps more importantly, we are now talking about sentimental value, which has nothing at all to do with financial value. Something of little or no financial value may have great sentimental value; and there is no reason at all to suppose that either financial value or ownership has much to do with sentimental value - at least, not in any way as to make inheritance important. For instance: I might pass my childhood home as I walk along the street, and smile at some happy memory; that doesn't depend on my owning or expecting that I will own the building, though. Hence it's not so clear why the state may not confiscate it and sell it on the open market when my parents die; that will not erase my happy memories, and my not owning it would be unlikely to cause distress if I never had any expectation that it would be mine to begin with.

Having said that, while the community may have an interest in seizing the value of a house or goods worth more than a certain amount, it has little interest in many of the accoutrements of everyday life - the family photo albums, the china dogs, the old oak cabinet — and it cannot confiscate memories. And it's these things, which constitute precisely the stuff that would likely fall below the threshold of any plausible confiscatory inheritance tax, that carry the moral weight in relationships. Hence a confiscatory tax would likely do nothing to erode the bonds that exercise Nozick.

\section{Would a Confiscatory Inheritance Tax be Unjust?}

I conclude, then, that even if we think that there are moral reasons to institute a legal system that protects rights to bequeath and to inherit, there are also reasons, both moral and practical, not to. Whatever interest is served by inheritance is an interest that non-inheritors also have, and if they generate a right in the putative inheritor, they would presumably generate a comparable right in everyone else that must, at the very least, be taken seriously. And the claim of the non-inheritor is bolstered by an appeal to the moral value of equality, to the non-necessity (and sometimes utter incapability) of inheritance to do what morality would seem most likely to require of it, and to the fact that to make a fuss about inheriting things betrays a very strange view of human relationships from the off.

A confiscatory tax is not a solution to all social problems. The children of the wealthy will already benefit from their parents' wealth while their parents are still alive. Unless we are going to have a highly intrusive state, we cannot stop wealthier people raising their families in nicer houses, taking them on nicer holidays, paying for better educational opportunities, and all the rest of it. But in one sense, this rather makes one of the arguments for a confiscatory inheritance tax. Given that someone has already 
benefited from undeserved advantages, and we are not going to begrudge them those, ain't that enough?

What may linger is a concern that a confiscatory inheritance tax will not eliminate undeserved benefits trickling down the generations, because it is reasonable to expect that someone who has inherited nothing but a good education and happy childhood will still stand a greater chance of finding elite employment, the proceeds of which will benefit her children, than will someone who inherited neither. In this vein, Halliday points out that since inheritance is rarely an early-life event, "inheriting wealth probably makes little difference to the social position of the immediate inheritor". But, as he adds, "it acts as an important enabler and enhancer of that inheritor's ability to confer subsequent advantage on his or her children" (Halliday 2018, 6 (slightly modified)). The effects on the testator's children might therefore matter rather less than the effects on his grandchildren and great-grandchildren.

That ought to remind us that a confiscatory inheritance tax is not a cure-all. It is not enough to eliminate systemic inequality. Indeed, one can support the principle of inheritance and acknowledge this to be problem. Thus, while Nozick holds that bequest can be seen as the instantiation of a morally important bond between testator and recipient (" $[\mathrm{I}] \mathrm{t}$ is the donor who has earned the right to mark and serve her relational bonds by bequeathal"), he notes also that

bequests that are received sometimes then are passed on for generations to persons unknown to the original earner and donor, producing continuing inequalities of wealth and position. Their receiving is no expression or outgrowth of her intimate bonds. If it seems appropriate for her to pass on what she has earned to those she cherishes and chooses, we are far less certain it is appropriate when others do the same. The resulting inequalities seem unfair. (Nozick 1990, 30)

Still, the general point, that inheritance puts some people at an unfair advantage over others simply because of their ancestors, stands; and minimizing it is going to do something to remedy that injustice, both by limiting the liquid assets passing through the generations, and by helping to fund the kind of state that can provide the children of the poorest with decent chances.

There may still be good reasons to allow inheritance. I have nodded towards a couple, and there may be more. In addition, real-world law would have to contend with clever planning of inter vivos gifts that may mean that there is officially nothing in an apparently wealthy person's estate when he dies. However, we cannot thereby deduce that inheritance would be a matter of right. It isn't. Hence, though the practically optimal level would be a matter for further argument, a highly confiscatory inheritance tax is in principle something that a just state might consider.

\section{Coda: Where There's a Will, There's a Relative}

I contend that the denial of a right to inherit is worth considering on social justice grounds. But it would have other benefits that, while not themselves weighty enough to justify abandoning inheritance, certainly add icing to the cake. One of these is that removing inheritance rights would remove an incentive to end others' lives. 
How strong is the link between inheritance and concerns about homicide? That people are sometimes murdered for an inheritance is a trivial observation. English law-in paragraph 5(2)(c) of Schedule 21 to the Criminal Justice Act (2003)—specifies that the starting point when determining the minimum term of imprisonment for "a murder done in the expectation of gain as a result of the death" should be 30 years; this is in contrast to the starting point being set at 15 years for a more runof-the-mill murder. On the assumption that there is a hierarchy of wrong when it comes to murder, and that the length of a sentence tracks this, killing Aunt Mabel in the hope of inheriting from her estate is worse than killing her for some other reason. Moreover, English law here implicitly recognises that inheritance might motivate a murder that otherwise wouldn't have happened.

Something similar holds in respect of assisting suicide. Documents such as the Crown Prosecution Service's guidance on prosecutions for assisted dying seem to be informed by considerations to do with inheritance. Thus paragraph 43(6) of the Policy for Prosecutors in Respect of Cases of Encouraging or Assisting Suicide, updated in October 2014, lists as a factor weighing in favour of prosecution for assisting suicide that

the suspect was not wholly motivated by compassion; for example, the suspect was motivated by the prospect that he or she or a person closely connected to him or her stood to gain in some way from the death of the victim. ${ }^{9}$

The phrase "in some way" can obviously accommodate many interpretations, but it is reasonable to infer from the phrasing a concern about inheritance. There is no "and" function between the considerations in favour of prosecution: it is not that case that prosecution is more likely if (per paragraph 43(1)) the victim was under 18 and (per paragraph 43(2)) lacked capacity to reach an informed decision about suicide and (per paragraph 43(3)) had not reached a clear decision to commit suicide and the suspect stood to gain, and so on though all sixteen considerations. Each consideration is independent of the others; hence it looks to be entirely possible that prosecution would be considered irrespective of which, if any, of the other factors weighing in favour of prosecution obtain. If the suspect knows she stands to inherit from the victim's will, and there is reason to suspect that this is what motivated her involvement in the victim's suicide, there may be grounds for prosecution. How frequently this sort of thing eventuates need not concern us all that much: what matters is simply that the CPS admits that a person may be motivated by reasons other than compassion to assist in a suicide, and takes this into account when considering whether the kind of wrong that merits judicial attention has been committed.

But if the prospect of inheritance is admitted to be a possible motivation for bringing about or helping to bring about another's death, and if the law is concerned to prevent or to punish that, then it seems only a hop, a skip, and a jump to suggest that reducing or removing inheritance rights would have the desirable outcome of

\footnotetext{
9 https://www.cps.gov.uk/legal-guidance/policy-prosecutors-respect-cases-encouraging-or-assisting-suici de; emphasis mine.
} 
taking away that motivation - and presumably therefore of reducing the number of homicides within the community.

Elmer Palmer murdered his uncle because of what he thought he stood to inherit. Removing the justification for the thought that he might have inherited anything at all would have removed the motive. Had it not been for the institution of inheritance, Francis Palmer might have lived much longer.

Acknowledgements I am very grateful to my colleagues at Manchester for comments on early drafts of this paper, particularly to Margot Brazier, Simona Giordano, Søren Holm, and Bruce Wardhaugh, who all provided extensive, insightful, and valuable comments. One of the blind reviewers also made useful requests for clarification. I have not been able to accommodate all comments and queries, but the paper is much stronger for my having accommodated some of them. I would also like to note my thanks to Martin O'Neill, who was good enough to let me see a pre-publication copy of Stuart White's chapter.

Open Access This article is distributed under the terms of the Creative Commons Attribution 4.0 International License (http://creativecommons.org/licenses/by/4.0/), which permits unrestricted use, distribution, and reproduction in any medium, provided you give appropriate credit to the original author(s) and the source, provide a link to the Creative Commons license, and indicate if changes were made.

\section{References}

\section{Books, Papers and Chapters}

Anon. 2017. Death of the Death Tax: Taxing Inheritances is Falling Out of Favour. The Economist, 23 November 2017. https://www.economist.com/briefing/2017/11/23/taxing-inheritances-is-fallingout-of-favour. Accessed Sept 2018.

Anon. 2018. Deemed Disposition of Property. Government of Canada. https://www.canada.ca/en/reven ue-agency/services/tax/individuals/life-events/what-when-someone-died/deemed-disposition-prope rty.html. Accessed Sept 2018.

Boring, Nicolas. 2015. France. In Inheritance Laws in the Nineteenth and Twentieth Centuries. Washington DC: Law Library of Congress.

Dickens, Charles. 2003. Bleak House. London: Penguin.

Director of Public Prosecutions. 2018. Suicide: Policy for Prosecutors in Respect of Cases of Encouraging or Assisting Suicide. Crown Prosecution Service. https://www.cps.gov.uk/legal-guidance/polic y-prosecutors-respect-cases-encouraging-or-assisting-suicide. Accessed Sept 2018.

Dworkin, Ronald. 1995. Life's Dominion. London: Harper Collins.

Dworkin, Ronald. 1997. Taking Rights Seriously. London: Bloomsbury.

Fabre, Cécile. 2001. The Choice-Based Right to Bequeath. Analysis 61: 60-65.

Feinberg, Joel. 1987. The Moral Limits of the Criminal Law: Harm to Others, vol. 1. New York: Oxford UP.

Goré, Marie. 2012. Inheritance Law. In Introduction to French Law, ed. George Bermann and Etienne Picard. Alphen aan den Rijn: Kluwer.

Halliday, Daniel. 2018. The Inheritance of Wealth. Oxford: Oxford UP.

Hart, H.L.A. 1955. Are There Any Natural Rights? The Philosophical Review 64: 179-180.

Hart, H.L.A. 1982. Essays on Bentham. Oxford: Oxford UP.

Koran. 1994. London: Penguin.

Nozick, Robert. 1974. Anarchy, State, and Utopia. New York: Basic Books.

Nozick, Robert. 1990. The Examined Life. New York: Simon and Schuster.

Piketty, Thomas. 2014. Capital in the Twenty-First Century. London: Belknap.

Rabelais, François. 2006. Gargantua and Pantagruel. London: Penguin.

Rawls, John. 2003. Justice as Fairness. Cambridge, MA: Belknap.

Rawls, John. 2005. Political Liberalism. New York: Columbia UP. 
Steiner, Hillel. 1994. An Essay on Rights. Oxford: Blackwell.

Watson, John. 1960. The Reign of George III, 1760-1815. Oxford: Clarendon.

White, Stuart. 2018. Moral Objections to Inheritance Tax. In Taxation: Philosophical Perspectives, ed. Martin O'Neill and Shepley Orr. Oxford: Oxford UP.

Zola, Emile. 2014. Money. Oxford: Oxford World's Classics.

\section{Statutes}

Administration of Estates Act. 1925. https://www.legislation.gov.uk/ukpga/Geo5/15-16/23/part/IV. Accessed Sept 2018.

Civil Code (France). https://www.legifrance.gouv.fr/Traductions/en-English/Legifrance-translations. Accessed Sept 2018.

Inheritance (Provision for Family and Dependents) Act. (1975). https://www.legislation.gov.uk/ukpga /1975/63. Accessed Sept 2018

\section{Case Law}

Banks v Goodfellow. [1870]. LR 5 QB.

Edwards v Edwards. [2007]. EWHC 1119 (Ch).

Ilott (Respondent) v The Blue Cross and others (Appellants). [2017]. UKSC 17.

Nahajec v Fowle (in his capacity as executor of the estate of Nahajec, deceased and as beneficiary of the estate). [2017]. EW Misc 11 CC.

Riggs v. Palmer, 115 N.Y. 506 (1889).

Thompson v Ragget. [2018]. EWHC 688 (Ch).

Publisher's Note Springer Nature remains neutral with regard to jurisdictional claims in published maps and institutional affiliations. 